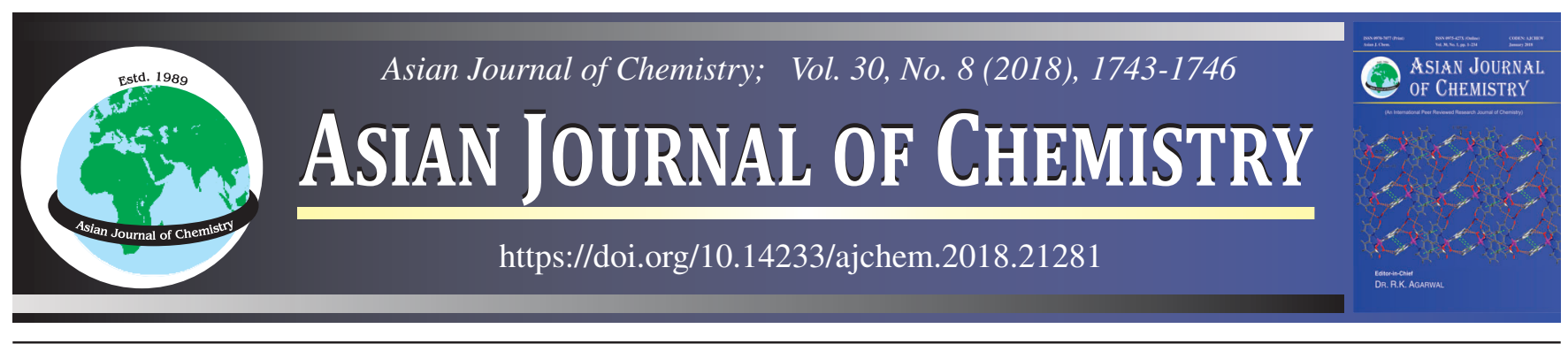

\title{
Comparison of Chemical Composition, Antimicrobial and Antioxidant Activities of Essential Oils Extracted from Different Parts of Bambangan (Mangifera pajang) Fruit
}

\author{
Lam Nyee Fan $^{1}$, Mohd Fadzelly Abu BakaR ${ }^{2,3, *}$, Noor Atiekah Md Nor ${ }^{1}$, Azlen Che Rahim ${ }^{2,3}$, \\ FaZleEn IzZANy Abu BaKaR ${ }^{2,3}$ and Mohd Aspollah Md SuKari ${ }^{4}$
}

${ }^{1}$ Institute for Tropical Biology and Conservation, Universiti Malaysia Sabah, Jalan UMS, 88400, Kota Kinabalu, Sabah, Malaysia ${ }^{2}$ Faculty of Applied Sciences and Technology, Universiti Tun Hussein Onn Malaysia, Hab Pendidikan Tinggi Pagoh, KM1, Jalan Panchor, 84600 Muar, Malaysia

${ }^{3}$ Centre of Research for Sustainable Uses of Natural Resources (CoR-SUNR), Universiti Tun Hussein Onn Malaysia, 86400 Parit Raja, Batu Pahat, Johor, Malaysia

${ }^{4}$ Department of Chemistry, Faculty of Science, Universiti Putra Malaysia, 43400 UPM, Serdang, Selangor, Malaysia

*Corresponding author: Fax: +60 6 9742191; Tel: +60 6 9742021; E-mail: fadzelly@uthm.edu.my

\section{INTRODUCTION}

There are approximately 70 species in the genus of Mangifera. 25 species of Mangifera can be found in Peninsular Malaysia, meanwhile 17 species of Mangifera can be found in Sabah, Malaysian Borneo. Bambangan or Mangifera pajang Kosterm. is the biggest fruit in the genus of Mangifera; up to $2 \mathrm{~kg}$ per fruit [1]. This species is endemic to Borneo Island and categorized as vulnerable by IUCN Red List of Threatened Species. It is found mainly in Borneo Island (Brunei Darussalam, Kalimantan (Indonesia), Sabah (Malaysia) and Sarawak (Malaysia) [2]. The flesh is yellowish, fibrous, thick with sweet and sour taste. The flesh of $M$. pajang is eaten fresh while the peel and kernel are used in cooking and made into pickle [1].

Several studies have been conducted on nutritional compositions of $M$. pajang $[1,3,4]$. Seed kernel of $M$. pajang was found to contain carbohydrate $(38.68 \%)$, protein $(3.08 \%)$, crude fibre $(4.79 \%)$, fat $(9.85 \%)$, ash (2.23\%) and water (41.38\%). Another study showed that the edible portion of fruit contained carbohydrate $(21.02 \%)$, protein $(1.13 \%)$, crude fibre $(5.26 \%)$, fat $(1.98 \%)$ and ash $(0.43 \%)$ while fibre-rich peel contained carbohydrate $(7.3 \%)$, protein $(4.6 \%)$, total dietary fibre $(72.3 \%)$, fat $(2.9 \%)$, ash $(2.7 \%)$ and moisture $(3.9 \%)$ [4].

Kernel extract of $M$. pajang showed a high potential as a potent cytotoxic agent against breast cancer cell lines as it induced cytotoxicity in MCF-7 (hormone-dependent breast cancer) cells and MDA-MD-231 (non-hormone dependent breast cancer) cells with $\mathrm{IC}_{50}$ values of 23 and $30.5 \mu \mathrm{g} / \mathrm{mL}$ respectively [5]. Besides, kernel and peel of $M$. Pajang considered as the waste of the fruit showed better anticancer potential as compared to flesh [2].

For the antioxidant effects, the methanolic extract of $M$. pajang kernel displayed the highest free radical scavenging and ferric reducing activities. Kernel possessed the highest 2,2diphenyl-1-pycryl-hydrazyl (DPPH) free radical scavenging (23.23 mg AEAC/g), followed by peel (20.32 mg AEAC/g) and flesh (9.94 mg AEAC/g) [6]. Meanwhile, DPPH assay on 
carotenoids extract of peel exhibited higher radical scavenging activity than its pulp [7]. Crude polysaccharide of this fruit and its fractions also showed strong antioxidant activities; the acidic polysaccharides had the highest antioxidant activity with $81.4 \%$ at $100 \mu \mathrm{g} / \mathrm{mL}$ extract [8]. A study found that the optimum extraction conditions for highest recovery of antioxidant capacities were $68 \%, 56^{\circ} \mathrm{C}$ and $31.8 \mathrm{~mL} / \mathrm{g}$, respectively where the predicted values agreed well with the experimental values [9]. In addition, Abu Bakar et al. [10] further confirmed the antioxidant activity at the cellular level of which M. Pajang kernel extract displayed cytoprotective activity against tert-butyl hydroperoxide induced oxidative damage [10].

There were many studies done on the volatile compounds from the Mangifera species $[11,12]$. However, there is still lack on the study of volatile constituents specifically from $M$. pajang. This study, therefore, aimed to identify the chemical composition, antimicrobial and antioxidant activities of essential oil extracted from flesh, peel and kernel of M. pajang (bambangan) using hydrodistillation.

\section{EXPERIMENTAL}

Sample preparation: The fruits of M. pajang were collected from Pasar Tamu Gaya, Kota Kinabalu, Sabah, Malaysia. The fruits were cleaned and separated into peel, flesh and kernel. Authentication of the fruits was done by Mr. Johnny Gisil from Institute for Tropical Biology and Conservation of Universiti Malaysia, Sabah, Malaysia. The peel, flesh and kernel were separated, cut into small pieces and stored in freezer $\left(-20^{\circ} \mathrm{C}\right)$.

Extraction: The flesh $(520 \mathrm{~g})$, peel $(500 \mathrm{~g})$ and kernel (500 g) of M. pajang were extracted separately by hydrodistillation method using Clavenger apparatus for $8 \mathrm{~h}$.

Gas chromatographic-mass spectral analysis (GC-MS): The $M$. pajang essential oils were then analyzed using Shimadzu GS-MS - QP5050 spectrophotometer equipped with Shimadzu GC-17A, HP5MS (5\% phenyl methylsilane) capillary column $(30 \times 250 \mu \mathrm{m} \times 0.25 \mu \mathrm{m})$ and helium as gas carrier. The GC oven temperature was programmed from $50^{\circ} \mathrm{C}$ to $250{ }^{\circ} \mathrm{C}$ at rate of $5^{\circ} \mathrm{C} / \mathrm{min}$ with an initial hold $1 \mathrm{~min}$ and final hold $10 \mathrm{~min}$. The constituents of oils were identified using GC-MS technique by comparing their mass spectral data with those from the Wiley mass spectral database and Kovat retention indices with the literature values.

2,2-Diphenyl-1-pycryl-hydrazyl (DPPH) free radical scavenging assay: The free radical scavenging ability of extract was determined according to the method described elsewhere [13]. DPPH solution ( $1 \mathrm{~mL}, 0.3 \mathrm{mM})$ was added to a $2.5 \mathrm{~mL}$ of sample extracts or standards. The mixture was then allowed to stand for $30 \mathrm{~min}$ in room temperature. The absorbance value was measured spectrophotometrically at $518 \mathrm{~nm}$ and the antioxidant activity (AA) was calculated as:

AA $\%=100-[($ Absorbance sample - Absorbance empty sample)/(Absorbance control)] $\times 100$

The result obtained was expressed as ascorbic acid equivalent antioxidant capacity (AEAC) using the following equations: $\mathrm{AEAC}=\left(\mathrm{IC}_{50}(\mathrm{AA}) / \mathrm{IC} 50(\right.$ sample $\left.)\right) \times 105$, where $\mathrm{AA}$ is ascorbic acid.

Antimicrobial assay: The disc diffusion method was used for screening the antimicrobial activity of isolated volatile oils using $6 \mathrm{~mm}$ sterile of filter discs [13]. Two Gram-positive bacteria (Stapyhlococcus aureus and Bacillus subtilis) and two Gramnegative bacteria (Escherichia coli and Salmonella enteritidis) were used. Microorganisms were cultured at $37^{\circ} \mathrm{C}$ for $24 \mathrm{~h}$ and prepared to turbidity equivalent to $0.5 \mathrm{McF}$ arland Standard. The suspension was added to the top of agar. Sterile discs were impregnated with four different concentration of essential oil (1000, 2000, 4000 and $5000 \mathrm{ppm}$ ) and places on the test plate (Muller Hinton agar). Distilled water was used as the negative control while kanamycin $(50 \mu \mathrm{g} / \mathrm{mL})$ was used as positive reference standards to determine the sensitivity of bacteria in each plates. Plates were subsequently incubated at the appropriate temperature for $24 \mathrm{~h}$ and zone of inhibition were calculated by using the diameter in $\mathrm{mm}$.

Statistical analysis: Data were expressed as mean \pm standard deviation of three triplicates. Statistical analysis was analyzed using SPSS (Statistical Package for the Social Sciences) through one-way ANOVA test followed by comparison of Tukey's post hoc. Difference on statistical analysis were considered significant at $\mathrm{p}<0.05$.

\section{RESULTS AND DISCUSSION}

Gas chromatographic-mass spectral analysis: The yields of essential oil from M. Pajang were $0.46 \%$ (flesh), $0.36 \%$ (peel) and $0.16 \%$ (kernel). In total, 56 volatile compounds from the essential oil of flesh, 9 volatile compounds from essential oil of peel and 26 volatile compounds from essential oil of kernel were identified by gas chromatography-mass spectrometry (GCMS). These compounds are listed in Table-1 with their retention time and percentage of concentration. Many volatile compounds were found in flesh, followed by kernel and peel. For the flesh part, the dominant compound was 3-methyl-4-cyclohexene (14.91\%) while $\alpha$-pinene (34.73\%) and linoleic acid (16.58 \%) were abundant in peel and kernel, respectively. Essential oil extracted from the flesh of $M$. pajang consisted of butanoic acid (1.0\%), 2-furancarboxalde (1.14\%), 1-hexanol (0.14\%), cyclopentane carboxylic acid $(0.14 \%), 2,7$-nonadien-5-one $(0.25$ $\%)$, butanoic acid $(0.25 \%)$, 2-furancarboxaldehyde $(0.26 \%)$, 8 -chlorocapric acid $(0.16 \%), \alpha$-phellandrene $(0.52 \%)$, bicyclo2-hept-2-ene $(0.40 \%)$, benzene $(0.63 \%)$, 2-furanmethanol (10.33\%), 3-methyl-4-cyclohexene (14.91\%), $\alpha$-methyl (2.07 $\%)$, undecane (1.95\%), benzene (1.24\%), 1,6-octadien-3-ol $(0.37 \%)$, phenylethyl alcohol $(0.30 \%)$, cyclohexen-1-ol ( 0.33 $\%), 2$-cyclohexen-1-ol (0.91\%), cyclohexanol (1.92\%), p-flouroethylbenzene $(0.06 \%), 4,4$-dimethyl-2-cyclopenten-1-one $(0.11 \%)$, cyclopropane $(1.14 \%)$, 3-cyclohexen-1-ol (0.68\%), benzene methanol (5.96\%), 3-cyclohexene-1-methanol (13.32 $\%)$, bicyclohexan-3-ol (7.51\%), bicyclohept-3-en-2-one (0.56 $\%), 2$-oxabicycloctanol-6-ol (0.54\%), 2-acetylcyclopentanone $(0.43 \%)$, ethanol (0.32\%), 2-cyclohexen-1-one (3.60\%), 2cycloyexen-1-one $(6.32 \%)$, acetic acid $(2.40 \%)$, 3-hexyne2,5-diol (2.13\%), cyclohexene (0.36\%), 3-hexyne-2,5-diol $(0.34 \%)$, phenol $(0.53 \%)$, cyclohexene $(0.33 \%), 10$-methyl8 -tetradecen-1-ol acetate (1.79\%), phenol (0.48\%), 7-octen3-ol $(0.30 \%)$, pentasiloxane $(9.68 \%)$, 2-acetoxydodecane $(0.54$ $\%), 5,7$-octadien-3-ol $(0.86 \%)$ and 2-bicycloheptanol $(0.49 \%)$. On the other hand, $\alpha$-pinene (34.73\%), cis-pinen-3-ol (0.09\%), $\beta$-pinene $(0.89 \%), \beta$-mycrene (1.62\%), $\alpha$-phellandrene (28.57 


\begin{tabular}{|c|c|c|c|c|}
\hline \multicolumn{5}{|c|}{$\begin{array}{c}\text { TABLE-1 } \\
\text { CHEMICAL COMPOSITION OF THE } \\
\text { ESSENTIAL OILS OF M. pajang }\end{array}$} \\
\hline \multirow{2}{*}{$\begin{array}{l}\mathrm{RT} \\
(\mathrm{min})\end{array}$} & \multirow{2}{*}{ Compound } & \multicolumn{3}{|c|}{ Concentration (\%) } \\
\hline & & Flesh & Peel & Kernel \\
\hline 5.305 & Butanoic acid & 0.57 & - & - \\
\hline 6.187 & 2-Furancarboxalde & 1.14 & - & - \\
\hline 6.694 & Butanoic acid & 0.11 & - & - \\
\hline 7.023 & 1-Hexanol & 0.14 & - & - \\
\hline 7.588 & $\alpha$-Pinene & - & 34.73 & 0.21 \\
\hline 8.082 & cis-Pinen-3-ol & - & 0.09 & - \\
\hline 8.593 & $\beta$-Pinene & - & 0.89 & - \\
\hline 8.766 & $\beta$-Mycrene & - & 1.62 & 0.27 \\
\hline 8.575 & Cyclopentanecarboxylic acid & 0.14 & - & - \\
\hline 8.704 & 2,7-Nonadien-5-one & 0.25 & - & - \\
\hline 9.327 & Butanoic acid & 0.25 & - & - \\
\hline 10.207 & 2-Furancarboxaldehyde & 0.26 & - & - \\
\hline 10.684 & 8-Chlorocapric acid & 0.16 & - & - \\
\hline \multirow[t]{2}{*}{11.145} & $\alpha$-Phellandrene & 0.52 & 28.57 & 6.03 \\
\hline & 1,3-Cyclohexadiene & - & 0.15 & 0.03 \\
\hline 11.477 & Bicycle-2-hept-2-ene & 0.40 & - & - \\
\hline \multirow[t]{3}{*}{11.850} & Benzene & 0.63 & 7.65 & 1.15 \\
\hline & D-Limonene & - & 12.55 & 2.16 \\
\hline & $\beta$-Phellandrene & - & 7.18 & 1.83 \\
\hline 13.442 & 2-Furanmethanol & 10.33 & - & - \\
\hline 13.477 & 3-Methyl-4-cyclohexene & 14.91 & - & - \\
\hline 13.938 & $\alpha$-Methyl & 2.07 & - & - \\
\hline 14.017 & Undecane & 1.95 & - & - \\
\hline 14.100 & Benzene & 1.24 & - & - \\
\hline 14.340 & 1,6-Octadien-3-ol & 0.37 & - & - \\
\hline 15.096 & Phenylethyl alcohol & 0.30 & - & - \\
\hline 15.212 & Cyclohexen-1-ol & 0.33 & - & - \\
\hline 15.432 & Butanoic acid & 0.32 & - & - \\
\hline 15.806 & 2-cyclohexen-1-ol & 0.38 & - & 0.54 \\
\hline 16.043 & Cyclohexanol & 0.60 & - & - \\
\hline 16.383 & $p$-Flouroethylbenzene & 0.06 & - & - \\
\hline 16.613 & Cyclohexanol & 0.22 & - & - \\
\hline 16.684 & $\begin{array}{l}\text { 4,4-Dimethyl-2-cyclopenten-1- } \\
\text { one }\end{array}$ & 0.11 & - & - \\
\hline 16.796 & Cyclopropane & 1.14 & - & - \\
\hline 16.971 & 3-Cyclohexen-1-ol & 0.68 & - & - \\
\hline 17.292 & Benzenemethanol & 5.96 & - & - \\
\hline 17.464 & 3-Cyclohexene-1-methanol & 12.41 & - & - \\
\hline 17.564 & 3-Cyclohexene-1-methanol & 0.91 & - & - \\
\hline 17.725 & Bicyclohexan-3-ol & 4.97 & - & - \\
\hline 17.878 & Octadecanoic acid & - & - & 0.59 \\
\hline 17.917 & Bicyclohept-3-en-2-one & 0.56 & - & - \\
\hline 18.054 & 2-Oxabicycloctanol-6-ol & 0.54 & - & - \\
\hline 18.108 & Cyclohexanol & 0.31 & - & - \\
\hline 18.182 & 2-Cyclohexen-1-ol & 0.53 & - & - \\
\hline 18.344 & 2-Acetylcyclopentanone & 0.43 & - & - \\
\hline 18.600 & Ethanol & 0.32 & - & - \\
\hline 18.761 & Benzophenone & - & - & 1.11 \\
\hline 18.863 & Bicyclohexan-3-ol & 2.54 & - & - \\
\hline 19.011 & Cyclohexanol & 0.79 & - & - \\
\hline 19.044 & Heptadecane & - & - & 0.78 \\
\hline 19.108 & 2-Cyclohexen-1-one & 3.60 & - & - \\
\hline 19.259 & 2-Cycloyexen-1-one & 0.60 & - & - \\
\hline 19.433 & Acetic acid & 2.40 & - & - \\
\hline 19.910 & 3-Hexyne-2,5-diol & 2.13 & - & - \\
\hline 20.140 & Octadecanoic acid & - & - & 2.28 \\
\hline 20.357 & Cyclohexene & 0.36 & - & - \\
\hline 20.442 & 3-Hexyne-2,5-diol & 0.34 & - & - \\
\hline 20.537 & Phenol & 0.53 & - & - \\
\hline 20.913 & Cyclohexene & 0.33 & - & - \\
\hline 21.027 & 1,2-Benzenedicarboxylic acid & - & - & 1.43 \\
\hline
\end{tabular}

\begin{tabular}{llccc}
\hline 21.191 & $\begin{array}{l}\text { 10-Methyl-8-tetradecen-1-ol } \\
\text { acetate }\end{array}$ & 1.79 & - & - \\
21.324 & 2-Heptadecanone & - & - & 1.04 \\
21.528 & Hexadecanoic acid & - & - & 1.05 \\
21.967 & Phenol & 0.48 & - & - \\
22.021 & Dibutyl phthalate & - & - & 0.98 \\
22.192 & Hexadecanoic acid & - & - & 5.86 \\
23.207 & 9,12-Octadecadienoic acid & - & - & 1.26 \\
23.304 & 2-Nonadecanone & - & - & 2.27 \\
23.449 & 7-Octen-3-ol & 0.30 & - & - \\
23.819 & Linoleic acid & - & - & 16.58 \\
23.750 & Pentasiloxane & 9.68 & - & - \\
23.860 & 9-Octadecenoic acid & - & - & 12.35 \\
23.960 & 2-Cyclohexen-1-one & 5.72 & - & - \\
24.065 & Octadecanoic acid & - & - & 2.39 \\
24.288 & 2-Acetoxydodecane & 0.54 & - & - \\
24.492 & 2-Octanol & - & - & 0.98 \\
24.820 & Cyclopentane & - & - & 0.71 \\
26.006 & 5,7-Octadien-3-ol & 0.86 & - & - \\
26.575 & 2-Bicycloheptanol & 0.49 & - & - \\
27.003 & 1,2-Benzenedicarboxylic acid & - & - & 1.43 \\
28.971 & Squalene & - & - & 2.99 \\
\hline RT = Retention time & & & \\
\end{tabular}

$\%)$, 1,3-cyclohexadiene ( $0.15 \%)$, benzene (7.65\%), D-limonene (12.55\%) and $\alpha$-phellandrene (7.18\%) were found in M. pajang peel. For M. pajang kernel, the volatile compounds found were $\alpha$-pinene $(0.21 \%), \beta$-mycrene (0.27\%), $\alpha$-phellandrene (6.03 $\%), 1,3$-cyclohexadiene $(0.03 \%)$, benzene ( $1.15 \%)$, D-limonene (2.16\%), $\beta$-phellandrene (1.83\%), 2-cyclohexen-1-ol (0.54\%), benzophenone $(1.11 \%)$, heptadecane $(0.78 \%)$, octadecanoic acid $(5.26 \%), 1,2$-benzene dicarboxylic acid (1.43\%), 2-heptadecanone (1.04\%), hexadecanoic acid (6.91\%), dibutyl phthalate $(0.98 \%), 9,12$-octadecadienoic acid $(1.26 \%)$, 2-nonadecanone $(2.27 \%)$, linoleic acid (16.58\%), 9-octadecenoic acid (12.35 $\%)$, 2-octanol (0.98\%), cyclopentane (0.71\%), 1,2-benzene dicarboxylic acid $(1.43 \%)$ and squalene $(2.99 \%)$. Other study isolated 50 volatile compounds from the pulp of $M$. pajang with 15 monoterpene hydrocarbons were found to be dominant chemical class. For instance, $\alpha$-pinene (67.2\%) and $\alpha$-phellandrene (11.0\%) [14]. Apart from this, the second most abundant chemical class in M. pajang pulp was esters $(\mathrm{n}=19)$ and of these, ethyl butanoate $(3.85 \%)$ and butyl butanoate $(3.38 \%)$ were the most abundant [14].

2,2-Diphenyl-1-pycryl-hydrazyl (DPPH) free radical scavenging assay: DPPH free radical scavenging assay is commonly used to determine the antioxidant activity. In this study, M. pajang peel displayed the highest radical scavenging activity with $64.4 \%$, followed by flesh and kernel with 61.6 and $52.2 \%$, respectively (Table-2). Other study reported that the DPPH radical scavenging activity of $M$. pajang pulp and juice powder were 43.25 and $52.61 \%$, respectively [4], showing that the results were lower than that of M. pajang peel and flesh in this study. Crude polysaccharide isolated and purified from M. pajang fibrous pulp displayed low radical scavenging activity (38.3\%) [9] compared to this study. The ethyl acetate and methanolic extracts of $M$. pajang kernel also showed high radical scavenging activity with $\mathrm{IC}_{50}$ values of 7.28 and $8.84 \mu \mathrm{g} / \mathrm{mL}$, respectively [15].

Antimicrobial assay: To the best of our knowledge, this is the first report on antimicrobial of essential oils extracted 


\begin{tabular}{|c|c|c|}
\hline \multicolumn{3}{|c|}{$\begin{array}{c}\text { TABLE-2 } \\
\text { FREE RADICAL SCAVENGING ACTIVITY } \\
\text { OF ESSENTIAL OIL OF } M \text {. Pajang }\end{array}$} \\
\hline Samples & $\mathrm{DPPH}^{*}$ & $\begin{array}{c}\text { Radical scavenging } \\
\text { activity }(\%)\end{array}$ \\
\hline Flesh & $68.8 \pm 0.19$ & 61.6 \\
\hline Peel & $80.7 \pm 0.35$ & 64.4 \\
\hline Kernel & $48.7 \pm 0.25$ & 52.2 \\
\hline
\end{tabular}

*DPPH free radical scavenging was expressed as mg ascorbic acid equivalent antioxidant capacity (AEAC).

from $M$. pajang against several pathogenic microorganisms by disc diffusion method (Table-3). Essential oils from flesh, peel and kernel of $M$. pajang were tested against Gram-positive bacteria (Staphylococcus aureus and Bacillus subtilis) and Gram-negative bacteria (Salmonella enteritidis and Escherichia coli). The results revealed that the essential oil extracted from different parts of the fruit were more sensitive against Grampositive bacteria. However, M. pajang peel was considered to show weak inhibition against $B$. subtilis $(5.3 \pm 0.4 \mathrm{~mm})$ followed by flesh against $B$. subtilis $(5.1 \pm 0.3 \mathrm{~mm})$ and kernel against $S$. aureus $(4.0 \pm 1.3 \mathrm{~mm})$. The antimicrobial activity against Gram-negative bacteria was lower due to the existence of outer membrane layer which prevent absorption of hydrophobic component through the lipopolysaccharide layer [16]. Previous study also indicated that most of the crude extracts of this fruit did not show significant inhibition activity against targeted microbes of which most of them displayed either weak or moderate activities with inhibition zones between 6 and $13 \mathrm{~mm}$ [15].

\begin{tabular}{ccccc}
\multicolumn{5}{c}{ TABLE-3 } \\
ANTIMICROBIAL ACTIVITIES (DIAMETER OF \\
INHIBITION ZONE) ESSENTIAL OIL OF M. Pajang \\
\hline \multirow{2}{*}{ Samples } & \multicolumn{4}{c}{ Inhibition zone (mm) } \\
\cline { 2 - 5 } & S. aureus & B. subtilis & E. coli & S. enteritidis \\
\hline Flesh & $2.2 \pm 0.5$ & $5.1 \pm 03$ & $2.1 \pm 1.1$ & $1.1 \pm 0.1$ \\
Peel & $1.7 \pm 0.8$ & $5.3 \pm 0.4$ & $2.0 \pm 0.3$ & $1.3 \pm 0.5$ \\
Kernel & $4.0 \pm 1.3$ & $2.8 \pm 0.5$ & $2.6 \pm 1.4$ & $1.1 \pm 0.1$ \\
\hline
\end{tabular}

\section{Conclusion}

The volatile compounds of Mangifera pajang peel showed the highest concentration with $\alpha$-pinene $(34.73 \%)$, followed by kernel and flesh with linoleic acid (16.58\%) and 3-methyl4-cyclohexane (14.91\%), respectively. Meanwhile, the essential oil of peel displayed the highest free radical scavenging for antioxidant activity in vitro. For antimicrobial activity, the essential oil of all parts of M. pajang showed weak inhibition.

\section{ACKNOWLEDGEMENTS}

This research was financially supported by Ministry of Higher Education of Malaysia (MOHE) under Fundamental
Research Grant Scheme, FRGS (Project no. 1560) entitled "Characterization of bioactive molecules from bark, leaf and fruit of bambangan (Mangifera pajang) extract to regulate cell cycle arrest and apoptosis in breast cancer cells, towards developing a novel low-toxic cancer therapy". The authors also thank Universiti Malaysia Sabah (UMS) and Universiti Tun Hussein Onn Malaysia (UTHM) for the use of the laboratory facilities and technical assistance.

\section{REFERENCES}

1. J. Tangah, F.E. Bajau, W. Jilimin, H.T. Chan, S.K. Wong and E.W.C. Chan, Syst. Rev. Pharm., 8, 86 (2017); https://doi.org/10.5530/srp.2017.1.15.

2. M. Fadzelly Abu Bakar, M. Mohamed, A. Rahmat, S.A. Burr and J.R. Fry, Nutr. Food Sci., 40, 29 (2010); https://doi.org/10.1108/00346651011015890.

3. F.A. Hassan, A. Ismail, A.A. Hamid, A. Azlan and S.H. Al-Sheraji, Food Chem., 126, 283 (2011); https://doi.org/10.1016/j.foodchem.2010.11.019.

4. M. Ibrahim, K.N. Prasad, A. Ismail, A. Azlan and A.A. Hamid, Afr. J. Biotechnol., 9, 4392 (2010).

5. M.F. Abu Bakar, M. Mohamad, A. Rahmat, S.A. Burr and J.R. Fry, Food Chem. Toxicol., 48, 1688 (2010); https://doi.org/10.1016/j.fct.2010.03.046.

6. M.F. Abu Bakar, M. Mohamed, A. Rahmat and J. Fry, Food Chem., 113, 479 (2009); https://doi.org/10.1016/j.foodchem.2008.07.081.

7. H.-E. Khoo, K.N. Prasad, A. Ismail and N. Mohd-Esa, Molecules, 15, 6699 (2010); https://doi.org/10.3390/molecules15106699.

8. S.H. Al-Sheraji, A. Ismail, M.Y. Manap, S. Mustafa, R.M. Yusof and F.A. Hassan, LWT-Food Sci. Technol., 48, 291 (2012); https://doi.org/10.1016/j.lwt.2012.04.002.

9. K.N. Prasad, F.A. Hassan, B. Yang, K.W. Kong, R.N. Ramanan, A. Azlan and A. Ismail, Food Chem., 128, 1121 (2011); https://doi.org/10.1016/j.foodchem.2011.03.105.

10. M.F. Abu Bakar, M. Mohamed, A. Rahmat, S.A. Burr and J.R. Fry, Food Chem., 136, 18 (2013); https://doi.org/10.1016/j.foodchem.2012.07.099.

11. O.J. Alwala, W. Wanzala, R.A. Inyambukho, E.M. Osundwa and I.O. Ndiege, J. Essent. Oil-Bear. Plants, 13, 85 (2010); https://doi.org/10.1080/0972060X.2010.10643795.

12. H.W. Wang, Y.Q. Liu, S.L. Wei, Z.J. Yan and K. Lu, Molecules, 15, 7715 (2010); https://doi.org/10.3390/molecules 15117715.

13. D. Ricci, D. Fraternale, L. Giamperi, A. Bucchini, F. Epifano, G. Burini and M. Curini, J. Ethnopharmacol., 98, 195 (2005); https://doi.org/10.1016/j.jep.2005.01.022.

14. K.C. Wong and S.S. Siew, Flav. Fragr. J., 9, 173 (1994); https://doi.org/10.1002/ffj.2730090406.

15. S. Ahmad, M.A. Sukari, N. Ismail, I.S. Ismail, A.B. Abdul, M.F. Abu Bakar, N. Kifli and G.C.L. Ee, BMC Complement. Altern. Med., 15, 83 (2015); https://doi.org/10.1186/s12906-015-0594-7.

16. M.B.H. Fredj, B. Marzouk, I. Chraief, K. Boukef and Z. Marzouk, J. Food Agric. Environ., 5, 52 (2007); https://doi.org/10.1234/4.2007.730. 